\title{
The Effect of Industry 4.0 on the Development of Micro, Small and Medium Enterprises (MSMEs) Banana Chips in Bandar Lampung
}

\author{
Helmia Adita Fitra ${ }^{1}$ \\ Department of Urban and Regional Planning, Institut Teknologi Sumatera, Lampung, Indonesia
}

\section{Fran Sinatra}

Department of Urban and Regional Planning, Institut Teknologi Sumatera, Lampung, Indonesia

\author{
Received : 3 October 2019 \\ Accepted : 29 August 2020 \\ Available Online : 31 August 2020
}

\begin{abstract}
Industry 4.0 fosters the local economy to be globalized because of technological innovation and the use of the internet. In Indonesia, MSMEs play a vital role in determining national economic performance. In the era of industry 4.0, MSMEs in Indonesia must adopt the technological changes affected by Industry 4.0; otherwise, their business loses competitiveness in the future. To win the competitiveness in the era of industry 4.0, Banana chips MSMEs should formulate the strategies which address the technological improvement and innovation on the component of MSMEs development. This study aims to examine the effect of industry 4.0 on the aspects of MSMEs development, pervades production and infrastructure, networking and financing support, sales and marketing, and human resources. This study used a quantitative approach and conducted a regression analysis to discover which aspect is affected by Industry 4.0. The results of the study revealed that only two components of Banana Chips MSMEs development affected industry 4.0. They are the component of sales and marketing and human resources components.
\end{abstract}

Keywords: banana chips MSMEs; industry 4.0; Lampung; regression

\section{Introduction}

Industry 4.0 brings many changes and challenges to Small Medium Enterprises (SMEs) such as adaption to the new disruptive technology resulting in the implementation of Information Technology (IT) systems and its infrastructure as the core requirement (Pereshybkina, Castillo Conde, \& Kalyesubula, 2017). Commonly, disruptive technology shifts or transforms the current ways or methods of doing things Chishakwe \& Smith (2012) since disruptive technology supersedes the incumbent technology from the mainstream system (Adner \& Zemsky, 2005). Disruptive technology clearly emphasizes easiness in terms of reducing mobility in order to meet peoples' needs. Markides (2006) also summarized that disruptive technology led to business model innovation and radical

\footnotetext{
${ }^{1}$ Corresponding Author: Department of Urban and Regional Planning, Institut Teknologi Sumatera, Lampung, Indonesia Email: helmia@pwk.itera.ac.id
} 
product innovations which highlighted several performance attributes in business such as 24-hour access, convenience, cheaper price, low commission rates, speed of execution, higher quality of skill, better design, size and quality and also user-friendliness. In the context of regional development, disruptive technology opens the globalizing economy, while technological innovation is quite significant for business development in the future (Nie, 2007). In Indonesia, the platform of disruptive technology has been defined since the launching of GOJEK. This company provides many services based on an online platform such as transportation services and other services like online payment, massage, cleaning services, and others, since 2010 in several big cities of Indonesia (Nurhajati, Rachma, Deka, \& Azwar, 2018).

The growing interest in regional development, Cecora (2000) confirmed that regional economies with a large proportion of Small Medium Enterprises (SMEs) have a lower entry barrier to new firms. It means that the existence of SMEs can strengthen indigenous development. The SMEs' performance is quite esential to raise productivity, performance delivery, and value addition to the business and its society. Smallbone \& Welter (2001) even added that the development of SMEs' development could help to the process of social transformation from a socialist to democratic since SMEs allow self-employment and selfhelp in case of developing small businesses. Moreover, in a broader context, SMEs have become a key player in the regional development process. Further, SMEs can play its role in growing the regional development not only by its number of entrepreneurship but also it is quality as well because it also promotes the employment and local economic development (Fernández-Serrano \& Romero, 2013).

The effect of disruptive technology in SMEs urged to be examined in order to enhance their adaption in maintaining their business competitiveness. Facing the Industry 4.0 era, Nie (2007) deplored that the adoption rate of technological innovation in SMEs is much slower than the large companies. Chishakwe \& Smith (2012) corroborated that disruptive technology has become the most grueling challenge faced by Small and Medium Enterprises (SME). For example, in developing nations, SMEs in South Africa are overwhelmed with adopting technological innovations to boost the success of business entities. The challenges of disruptive technology also alarm SMEs in developed nations. German SMEs also struggled in facing disruptive technology. Only 5\% of German SMEs have already adopted the new disruptive technologies since the data security is unstandardized yet for collaboration innovation and value chain networks (Chishakwe \& Smith, 2012). Also, the workplace modification and fewer jobs have triggered the government to take action for its successful adoption (Pereshybkina et al., 2017).

In Indonesia, Micro, Small, and Medium Enterprises (MSMEs) play a significant role in economic growth and social inclusion (OECD, 2018). MSMEs in Indonesia have been regulated in Law Number 20 in 2008 concerning on Micro, Small and Medium Enterprises (MSMEs). There are several definitions and criteria for MSMEs. MSMEs have the following criteria: (1) micro businesses, namely productive businesses owned by individuals; (2) small-scale businesses namely independent economic productive ventures carried out by individuals or business entities that are not subsidiaries or non-branch companies that are owned, controlled or become a part either directly or indirectly of medium-sized businesses or large businesses, and (3) medium-sized businesses, i.e., productive economic enterprises that stand-alone, which are carried out by individuals or business entities that are not subsidiaries or branch companies that are owned, controlled and become part either directly or indirectly with small businesses or large businesses.

Referring to the data from the Ministry of Co-operative and SMEs Indonesian, MSMEs in Indonesia have dominated the percentage of employment, which reached around $97 \%$ and $56 \%$ for business investment (OECD, 2018). In response to Industry 4.0, the Indonesian government formulated an industrial policy in facing the era of disruptive 
technology (Sulaksono, 2018). Law no. 3 of 2014 about the National Industry puts the industrial sector as one of the primary economic sectors in Indonesia. As one of the strategies in pursuing the vision of the national industry, the Indonesian government formulates an affirmative policy for small and medium industries (Ministry of Industry, 2015).

As the gate of Sumatera and also the provincial capital of Lampung Province, Bandar Lampung has a strategic position in regional development, which can bring benefits for its economic development. Based on the data of Central Bureau of Statistics of Bandar Lampung (2016), in 2014, the number of industrial units in Bandar Lampung reached 9,908 units, which is classified as three categories. They are medium-large industry, small industry, and home industry. According to the data, the number of home industries has dominated the percentage of industrial units, which reached about $75 \%$, whereas small industries have only $23 \%$ and medium-large industries are no more than $2 \%$. Data from the Central Bureau of Statistics of Bandar Lampung (2016) revealed that the home industry in Bandar Lampung has the biggest number, among other categories.

In terms of SMEs' commodity, Banana chips are the most popular product in Bandar Lampung, which is produced by mostly the home industry in Bandar Lampung. Banana chips industries have also been seen as a significant asset to foster local economic development in Lampung Province. According to the rise of concerns about disruptive technology, MSMEs Banana Chips in Bandar Lampung are on the same boat with others, which have to boost their level of technological innovation and adopt the disruption well just to keep their business sustained. Industry 4.0 creates a new trend in MSMEs development. The previous study about MSMEs development in Industry 4.0 era has been explored that technological innovation becomes the most needed thing to be adopted in order to win the business competitiveness in the future (Matt \& Rauch, 2020). Many studies have been conducted, yet they highlight or focus on the sole component of MSMEs development. Among the previous studies about SME's development, this study scours to what extent the effect of industry 4.0 to multi development components of MSMEs comprises the production and infrastructure, networking and financing support, sales and marketing, also human resources. Hence, this study aims to examine the effect of industry 4.0 on the aspects of MSMEs development, pervades production and infrastructure, networking and financing support, sales and marketing, and human resources. This study sees if the application of technological innovation, as the consequence Industry 4.0, effects those aspects of MSMEs development in the case of Banana Chips MSMEs in Bandar Lampung.

\section{Method}

The study is conducted in Jl. Pagar Alam, Bandar Lampung, which is well known as" Gang PU," an icon of MSMEs Banana Chips in Bandar Lampung. This study was conducted through a census of 23 units of Banana Chips MSME in Gang PU. This study set the time frame for the data needs because the needs to see the changing situation experienced by MSMEs before and during the Industry 4.0 era. Therefore, this research requires data in 2017, since the Gojek began operating for the first time as an Industry 4.0 platform in Bandar Lampung. This study also uses data from 2012 because this study was designed to observe five years before GOJEK's first operation in Bandar Lampung. This study ran the regression analysis in order to examine to what extent the technological innovation, as the feature of Industry 4.0, affects the development components of Banana Chips MSMEs. Although the study runs the regression analysis, the interpretation of findings is also supported by the interview with some owners of Banana Chips MSMEs in Gang PU. The interview is conducted in order to affirm and to corroboration the findings. Therefore, this 
study target those who are already set their business in 2012 and keep it until 2017 or even more. The list of respondents is P1 (for Mrs. Nurila, the owner of Puri Jaya), and P2 (for Mr. M. Idris Siregar, the owner of Kripik Yaya). Those are recommended by Cooperatives and MSMEs Office of Bandar Lampung to be interviewed since they undergo the circumstances which suited with the research time frame.

To limit the scope of study, this study uses variables which are derived from Cahyanti \& Anjaningrum (2017) that stated clearly about some factors that influence the development of MSMEs: (1) human resources, (2) production and infrastructure, (3) sales and marketing (4) networking and financing support. Each variable is designed with the technological changes as the nature of industry 4.0, resulting in some natures such as the higher quality of human resources, easiness, the use of internet of things, and the automation for each factor of MSMEs development as they become the requirements for Industry 4.0. Thus, the dependent variables are defined from the positive change experienced by Banana Chips MSMEs in 2012 (five years before the launching of GOJEK) and 2017 (the year of the launching of GOJEK in Bandar Lampung). The regression analysis will run for each influencing variable resulting in four models of regression analysis. The first analysis shows the effect of industry 4.0 on the material supply aspect. Second, the analysis shows the effect of industry 4.0 on financial and licensing support. Third, the analysis reveals the effect of industry 4.0 on product sales. Last, the analysis shows the effect of industry on human resources. Each analysis has developed the predictor variables as shown in Table 1.

Table 1. Variables

\begin{tabular}{|c|c|c|c|}
\hline No & Aspect & Dependent Variable & Predictor Variables \\
\hline 1 & $\begin{array}{l}\text { Production and } \\
\text { Infrastructure }\end{array}$ & $\begin{array}{l}\text { The changes in the } \\
\text { amount of material } \\
\text { supply in } 2012 \text { and } 2017 \\
\text { (in Kg) }\end{array}$ & $\begin{array}{l}\text { 1. Internet-based material supply activity } \\
\text { 2. The use of high-technology in material } \\
\text { storage } \\
\text { 3. The percentage of decayed material during } \\
\text { shipping } \\
\text { 4. Shipping duration }\end{array}$ \\
\hline 2 & $\begin{array}{l}\text { Networking and } \\
\text { Financing Support }\end{array}$ & $\begin{array}{l}\text { The changes in the } \\
\text { amount of credit } \\
\text { obtained in } 2012 \text { and } \\
2017 \text { (in Million Rupiah) }\end{array}$ & $\begin{array}{l}\text { 1. Internet-based credit application } \\
\text { 2. The percentage of approved credit } \\
\text { 3. Duration of the credit application } \\
\text { 4. Duration of credit approval }\end{array}$ \\
\hline 3 & Sales and Marketing & $\begin{array}{l}\text { The changes in the } \\
\text { number of sales in } 2012 \\
\text { and } 2017 \text { (in Million } \\
\text { Rupiah) }\end{array}$ & $\begin{array}{l}\text { 1. The number of sales via the internet (using } \\
\text { online transaction) } \\
\text { 2. The number of sales by using delivery } \\
\text { service } \\
\text { 3. The number of sales abroad } \\
\text { 4. The number of sales outside Lampung } \\
\text { Province } \\
\text { 5. The number of sales outside Bandar } \\
\text { 6ampung }\end{array}$ \\
\hline 4 & Human Resources & $\begin{array}{l}\text { The changes in the } \\
\text { number of workers in } \\
2012 \text { and } 2017 \text { (in } \\
\text { person) }\end{array}$ & $\begin{array}{l}\text { 1. The number of programmer and machine } \\
\text { operator } \\
\text { 2. The number of packaging staff } \\
\text { 3. The number of marketing staff } \\
\text { 4. The percentage of labor that has higher } \\
\text { education }\end{array}$ \\
\hline
\end{tabular}




\title{
Result and Discussion
}

\section{Production and Infrastructure}

The key variable for the aspect of production and infrastructure is the material supply since the competitiveness of SMEs also depends upon their suppliers (Singh, 2011). The regression model resulted from the analysis, as shown in equation (1).

$$
Y=-575,69+269,62 X_{1}+120,93 X_{2}+91,18 X_{3}
$$

Notes: $\mathrm{Y}=$ the changes in the amount of material supply in 2012 and $2017 ; \mathrm{X}_{1}=$ the use of high technology in storage in 2017; $\mathrm{X}_{2}=$ the changes in the percentage of decayed materials in 2012 and 2017; and $X_{3}=$ the changes in shipping duration in 2012 and 2017.

This model can not be used since $\mathrm{R}^{2}$ value of the model is $0,001(<0,50)$. It means that the model can only represent less than $50 \%$ of the real condition. Moreover, according to the level of significance of its variables, all variables have more than 0,005 (see Table 2). It means that the predictor variables are not significant enough to create the model.

Table 2. Coefficients

\begin{tabular}{|c|c|c|c|c|c|c|}
\hline \multirow{2}{*}{\multicolumn{2}{|c|}{ Model }} & \multicolumn{2}{|c|}{ Unstandardized Coefficients } & \multirow{2}{*}{$\frac{\text { Standardized Coefficients }}{\text { Beta }}$} & \multirow{2}{*}{$t$} & \multirow{2}{*}{ Sig. } \\
\hline & & B & Std. Error & & & \\
\hline \multirow[t]{4}{*}{1} & (Constant) & -575.694 & 5280.651 & & -.109 & .914 \\
\hline & Storage_technology & 269.628 & 3188.800 & .023 & .085 & .934 \\
\hline & Decayed_materials & 120.929 & 1171.486 & .027 & .103 & .919 \\
\hline & Shipping_duration & 91.182 & 1245.394 & .018 & .073 & .942 \\
\hline
\end{tabular}

Notes: a. Dependent variable: the changes in the amount of material supply

The insignificant result can be assumed that either MSMEs Banana Chips in Bandar Lampung have not been affected yet by Industry 4.0 or they do not take any advantage of Industry 4.0 for their material supply. This finding is affirmed by P1 that contended:

\begin{abstract}
"...... in the past, we processed it ourselves from raw bananas, but many of them get rotten if we stored it for a long time. We are no longer process it from raw bananas, but the bananas are directly supplied from the banana chips supplier. Banana chips have not yet been given a flavor. Then, we need to add the flavor before it is sold. Indeed, there is less material damage now, but not because of using advanced technology, but because the bananas have been fried first. Apart from that, the supplier also provides it quickly. Today we contact the supplier, and bananas can arrive in the afternoon or tomorrow morning."
\end{abstract}

According to the affirmation from the respondent, the production of Banana Chips seems to not taking any advantage of technological innovation even in applying banana storage. In contrast, according to Raymond, Uwizeyemungu, Fabi, \& St-Pierre (2018), industrial SMEs must steadily be innovative to win the competition of globalized economy by implementing the technological innovation in creating new product development.

\section{Networking and Financing Support}

The amount of credit obtained is chosen as a variable dependent in this study since SMEs need a considerable capital to enlarge the production, improve the quality and brand (Cui, Zha, \& Zhan, 2010). The model of regression, as shown in equation (2).

$$
Y=0+50.629,16 X_{2}-36.620 .120,05 X_{3}+38.152 .427,95 X_{4}
$$


Notes: $Y=$ The changes in the amount of credit obtained in 2012 and 2017 (in Million Rupiah); $\mathrm{X}_{2}=$ The changes in the percentage of approved credit in 2012 and 2017; $\mathrm{X}_{3}=$ The changes in the duration of credit application in 2012 and 2017; and $\mathrm{X}_{4}=$ The changes in the duration of credit approval in 2012 and 2017.

The value of $\mathrm{R}^{2}$ is 0,968 , which means that the model can represent about $96,8 \%$ of real conditions. The model shows that Industry 4.0 has affected 3 of 4 variables in financial support (see Table 3). Table 3 presents the following results: first, the use of the internet in credit application $\left(\mathrm{X}_{1}\right)$ is insignificant since it has a level of significance around 0,067 $(>0,05)$. This condition can be understood because MSMEs still use conventional or manual submission to get financial support. It is shown by the data of respondents which are almost all unit MSME in Gang PU does not conduct internet-based credit submission. In line with the comment of the P2 as follows:

"........we usually owe money to relatives or friends because it is more quickly and less complicated. If we need more loans, we will borrow money from the bank, then fill out the form..... we do not know that there was a loan service using the internet."

Second, the changes in the duration of the credit application $\left(\mathrm{X}_{3}\right)$ variable is significant enough to $(0,049)$. The nature of the relationship between the duration of a credit application and the changes amount in credit obtained shows the opposite nature. It can be comprehended that almost all Banana Chips MSMEs conduct the conventional way in proposing credit application resulting in the long waiting time for a credit application. Third, the other two variables have positive effects on the changes in the amount of credit obtained. They are the changes in the percentage of approved credit $\left(\mathrm{X}_{2}\right)$ " and" the changes in the duration of credit approval $\left(\mathrm{X}_{4}\right)$ ". According to the data of respondents, many of them using the network to get the credit. Instead of proposing the bank to get the credit, they prefer to get the credit by their relation, their family or even their friends. These cause the shorter duration of credit approval since they do not have to follow some procedures as the bank does. According to the reason, we can not conclude that these two variables are affected by Industry 4.0 since they do not apply the technological innovation in the context of financing and networking aspect. Jones \& Jain (2002) said that SMEs should increase their business growth and decrease their financial risk by utilizing financial technology to maintain their competitiveness between SMEs and the larger competitors also among SMEs.

Table 3. Coefficients

\begin{tabular}{|c|c|c|c|c|c|c|c|c|}
\hline & \multirow[t]{2}{*}{ Model } & \multicolumn{2}{|c|}{$\begin{array}{l}\text { Unstandardized } \\
\text { Coefficients }\end{array}$} & \multirow{2}{*}{$\begin{array}{c}\begin{array}{c}\text { Standardized } \\
\text { Coefficients }\end{array} \\
\text { Beta } \\
\end{array}$} & \multirow[t]{2}{*}{ t } & \multirow[t]{2}{*}{ Sig. } & \multicolumn{2}{|c|}{$\begin{array}{c}\text { Collinearity } \\
\text { Statistics }\end{array}$} \\
\hline & & $\mathbf{B}$ & Std. Error & & & & Tolerance & VIF \\
\hline \multirow[t]{7}{*}{1} & (Constant) & -431969.935 & 807454.590 & & -.535 & .601 & & \\
\hline & Online_credit & -3464981.886 & 1752242.003 & -.122 & -1.977 & .067 & .560 & 1.787 \\
\hline & Aprroved_credit & 50629.162 & 23653.536 & .146 & 2.140 & .049 & .461 & 2.171 \\
\hline & Duration_application & -36620120.055 & 2204150.499 & -1.924 & -16.614 & .000 & .159 & 6.286 \\
\hline & Duration_approval & 38152427.104 & 2493537.919 & 2.148 & 15.301 & .000 & .108 & 9.237 \\
\hline & Duration_permittion & -311246.950 & 205729.351 & -.081 & -1.513 & .151 & .742 & 1.347 \\
\hline & Online permittion & 2548361.387 & 1468486.314 & .107 & 1.735 & .103 & .560 & 1.786 \\
\hline
\end{tabular}

Notes: a. Dependent variable: credit_obtained

\section{Sales and Marketing}

The changes in the number of sales are chosen as key variables since the sales growth can be used in determining the success of business life (Chittithaworn, Islam, Keawchana, \& Yusuf, 2011). By using regression analysis, the study about the impact of 
industry 4.0 on the sales of MSMEs Banana Chips products can be revealed. The regression model, as shown in equation (3).

$$
\mathrm{Y}=-39.130,96+21.842,16 \mathrm{X}_{1}
$$

Notes: $\mathrm{Y}=$ The number of sold banana chips products (Banana Chips) $(\mathrm{kg})$; $\mathrm{X}_{1}=$ Internetbased product promotion; The value of $\mathrm{R}^{2}$ of the model is 0,594 . The values are assumed that variables included in the model can represent about $59,4 \%$ of real conditions. Referring to the model, it is shown that only one significant independent variable, while the other variables are not significant enough to determine the model since they have the level of significance is higher than 0,05 (see Table 4).

Table 4. Coefficients

\begin{tabular}{llrrrrr}
\hline \multirow{2}{*}{ Model } & \multicolumn{2}{c}{$\begin{array}{c}\text { Unstandardized } \\
\text { Coefficients }\end{array}$} & $\begin{array}{c}\text { Standardized } \\
\text { Coefficients }\end{array}$ & \multirow{2}{*}{ t } & \multirow{2}{*}{ Sig. } \\
\cline { 3 - 5 } & \multicolumn{1}{c}{ B } & Std. Error & Beta & & \\
\hline 1 & (Constant) & -39130.969 & 8757.019 & & -4.469 & .000 \\
& Online_marketing & 21842.169 & 5652.278 & .792 & 3.864 & .002 \\
& Delivery_service & 42.011 & 51.083 & .196 & .822 & .424 \\
Online_transaction & -1.413 & 3.294 & -.091 & -.429 & .674 \\
& International_market & -33.777 & 36.859 & -.208 & -.916 & .374 \\
& Regional_market & 17.139 & 30.361 & .162 & .564 & .581 \\
& Local_market & 21.636 & 52.023 & .073 & .416 & .683 \\
\hline Notes: a. Dependent variable: sold product & & & & &
\end{tabular}

The significant independent variable is "internet-based product promotion." It means that the marketing strategy has adopted technological innovation by using internet basedpromotion media. The model also reveals that Industry 4.0 has not affected all aspects of the sales product except the promotion with internet-based only. MSMEs Banana Chips in Bandar Lampung already use the social media and internet to promote and market their product by using some internet features such as Instagram, WhatsApp, Facebook and any online shop in line with the reviews from the P2 as follows:

"... yes, we use WhatsApp, Facebook, Instagram, and Buka Lapak."

By using the online platform for the promotion, the Banana chips MSMEs in Bandar Lampung have been adopting technological innovation in product marketing and sales. Handayani \& Lisdianingrum (2011) revealed that by using free online marketing for SMEs' products, they have been establishing an excellent strategy to broaden their market, to fasten the transactions, and to give a better customer service also to save the cost of marketing campaign.

\section{Human Resources}

The changes in the number of labors are defined as key variables since Industry 4.0 creates new technological trends and opportunities resulting in the automation tasks. It means the future job will shift from conventional skill to technological skill. As a consequence, the future job requires no longer the quantity but the skill to face the new trends (Maresova et al., 2018). The regression model, as shown in equation (4).

$$
Y=-1,2+1,29 X_{1}+1,09 X_{2}+0,32 X_{3}
$$


Notes: $\mathrm{Y}=$ the number of labors; $\mathrm{X}_{1}=$ the number of programmer or machine operator; $\mathrm{X}_{2}=$ the number of packaging staff; and $\mathrm{X}_{3}=$ the number of marketing staff.

According to the analysis, $\mathrm{R}^{2}$ of the model is 0,912 . It means that the variables included in the model can represent $91,2 \%$ of real conditions. The result shows that Industry 4.0 affects 3 of 4 predictor variables (see Table 5).

Table 5. Coefficients

\begin{tabular}{|c|c|c|c|c|c|c|}
\hline & \multirow[t]{2}{*}{ Model } & \multicolumn{2}{|c|}{ Unstandardized Coefficients } & \multirow{2}{*}{$\begin{array}{c}\begin{array}{c}\text { Standardized } \\
\text { Coefficients }\end{array} \\
\text { Beta }\end{array}$} & \multirow[t]{2}{*}{$\mathbf{t}$} & \multirow[t]{2}{*}{ Sig. } \\
\hline & & B & Std. Error & & & \\
\hline \multirow[t]{5}{*}{1} & (Constant) & -1.206 & .332 & & -3.629 & .002 \\
\hline & Quant_prog & 1.291 & .230 & .441 & 5.603 & .000 \\
\hline & Quant packaging staff & 1.099 & .145 & .666 & 7.602 & .000 \\
\hline & Quant_marketing_staff & .329 & .099 & .245 & 3.327 & .004 \\
\hline & Qual above sma & -.007 & .009 & -.067 & -.781 & .445 \\
\hline
\end{tabular}

Notes: a. Dependent variable: jml_pegawai

They are "the number of programmer or machine operator," a number of packaging staff," and" the number of marketing staff." However, labor with higher education is not significant enough to create a model. It can be assumed that industry 4.0 does not affect the education level of the worker. Instead of hiring the worker with higher-level education, MSMEs Banana Chips in Bandar Lampung prefer to hire the worker that masters the technological skill. This finding is going well with the P1 opinion as follows:

"We do not need workers who have a bachelor degree. We are worried that the salary we provide is not appropriate. More importantly, workers can operate social media as administrators and use a packaging tools because buyers rarely buy in stores. Buyers often ask for items to be shipped."

However, to strengthen the performance of Banana chips MSMEs in the future, the needs of human resources will be no longer focus on the number of workers yet the system of recruitment, selection, and retention in SMEs (Festing, 2007). It implicates that SMEs must prepare the well-established system in human resource management to overcome the human resources needs in the future. Omar, Arokiasamy, \& Ismail (2009) added that human resource development would be a significant tool to increase SME's development in the future.

\section{Conclusion}

This study conclude that not all components of SME's development have been affected by industry 4.0. The production and infrastructure of Banana Chips MSMEs have not been affected yet by Industry 4.0 because they still run the conventional methods to maintain their material supply. Same as the networking and financing support. Banana Chips MSMEs seems to resist the technological innovation in financing support. They tend to choose to maintain kinship with their family and friends to get financial assistance rather than applying banking innovations.

On the contrary, the other two aspects of Banana Chips MSMEs development are affected by Industry 4.0, such as (1) marketing, which is effected in sales and marketing of Banana Chips MSMEs in Bandar Lampung. It is shown by the use of an online platform to promote and market the product, such as social media and online shops. According to the regression model, the more online based-promotion activity, the more product sold, and (2) industry 4.0 also influences the changes in human resources needs in Banana Chips 
MSMEs in Bandar Lampung, which is no longer quantity oriented but more technological skill-oriented. It is proved by the regression model, which shows that the number of workers in Banana Chips MSMEs is determined by the needs of a programmer or machine operator, packing staff, and marketing staff. They are no longer need many workers to produce Banana Chips because they do not process the raw bananas into chips.

Regarding the findings, in order to sustain the MSMEs Banana Chips in Bandar Lampung, there are five strategies to win the era of industry 4.0: (1) socialization and mentoring program on the development of marketing and sales aspects of MSMEs Banana Chips which are designed to optimize utilizing the online media to boost their sales, conducted by at least the government, private sectors and academics; (2) the cooperation between the government and bank -or any finance institution- in order to facilitate the online transaction needs of MSMEs Banana Chips; (3) the cooperation between the government and business sector that is professional in providing delivery service not only in the local level and nationwide but also international market level in order to broaden the marketing and sales area; (4) enhancement of Bandar Lampung City Branding by collaboration among stakeholders such as governments, academics, business sectors in order to promote Banana Chips as a genuine product of Lampung; and (5) facilitation the academics in terms of research and development of innovative banana chips production both in terms of Banana product variants, flavor and packaging innovation.

According to the study, the result suggests there is a need for comprehensive understanding of the effect of industry 4.0 on the development of MSMEs in order to win the regional competitiveness, a need of information and communications technology in developing MSMEs as well as to manage their waste and also a need for putting more attention in purveying the competitive human resources.

\section{Acknowledgment}

We would like to express our gratitude to Institut Teknologi Sumatera for the research grant. Also, to our respondents, especially Mrs. Nurila, the owner of Puri Jaya and Mr. M. Idris Siregar, the owner of Kripik Yaya, and to our research assistants (Irfan, Nisfi, and Laura), who help us a lot in finishing this research within the limited time frame.

\section{References}

Adner, R., \& Zemsky, P. (2005). Disruptive technologies and the emergence of competition. RAND Journal of Economics, 36(2), 229-254.

Cahyanti, M. M., \& Anjaningrum, W. D. (2017). Faktor-faktor yang mempengaruhi perkembangan usaha kecil sektor industri pengolahan di Kota Malang. Jurnal Ilmiah Bisnis dan Ekonomi Asia, 11(2), 73-79. doi:10.32812/jibeka.v11i2.50.

Cecora, J. (2000). Entrepreneurs and SMEs in regional economies: Policy issues for sustainable development in a globalizing economy. International Review of Sociology, 19(1), 83-100. doi:10.1080/713673986.

Central Bureau of Statistics of Bandar Lampung. (2016). Bandar Lampung dalam angka. Bandar Lampung.

Chishakwe, D. B., \& Smith, W. (2012). An analysis of the impact of disruptive technology on the success of small and medium enterprises (SMEs) in a developing nation. A case of King Williams Town, South Africa. African Journal of Business Management, 6(36), 10050-10060. doi:10.5897/AJBM12.647.

Chittithaworn, C., Islam, M. A., Keawchana, T., \& Yusuf, D. H. M. (2011). Factors affecting business success of small \& medium enterprises (SMEs) in Thailand. Asian Social Science, 75), 180-190. doi:10.5539/ass.v7n5p180.

Cui, Y., Zha, L., \& Zhan, F. (2010). Financial support system and strategy of SMEs in the incubation based on business life cycle. International Business Research, 3(4), 119-123. 


\section{The Effect of Industry 4.0 on the Development of Micro, Small and Medium Enterprises .. .}

Fernández-Serrano, J., \& Romero, I. (2013). Entrepreneurial quality and regional development: Characterizing SME sectors in low income areas. Papers in Regional Science, 92(3), 495-513. doi:10.1111/j.14355957.2012.00421.x.

Festing, M. (2007). Globalisation of SMEs and implications for international human resource management research and practice. International Journal of Globalisation and Small Business, 2(1), 5-18. doi:10.1504/IJGSB.2007.014184.

Handayani, P. W., \& Lisdianingrum, W. (2011). Impact analysis on free online marketing using social network Facebook: Case study SMEs in Indonesia. In 2011 International Conference on Advanced Computer Science and Information Systems (pp. 171-176).

Jones, M., \& Jain, R. (2002). Technology transfer for SMEs: challenges and barriers. International Journal of Technology Transfer and Commercialisation, 1(1-2), 146-162. doi:10.1504/IJTTC.2002.001781.

Maresova, P., Soukal, I., Svobodova, L., Hedvicakova, M., Javanmardi, E., Selamat, A., \& Krejcar, O. (2018). Consequences of industry 4.0 in business and economics. Economies, 6(3), 46. doi:10.3390/economies6030046.

Markides, C. (2006). Disruptive innovation: In need of better theory. Journal of Product Innovation Management, 23(1), 19-25.

Matt, D. T., \& Rauch, E. (2020). SME 4.0: The role of small- and medium-sized enterprises in the digital transformation. In M. D, M. V, \& Z. H (Eds.), Industry 4.0 for SMEs: Challenges, Opportunities, and Requirements (pp. 3-36). Palgrave Macmillan, Cham. doi:10.1007/978-3-030-25425-4_1.

Ministry of Industry. (2015). Rencana induk pembangunan industri nasional 2015-2035. Jakarta.

Nie, J. (2007). A study of information technology adoption for small and medium sized enterprises strategic competitiveness. In 2007 International Conference on Wireless Communications, Networking and Mobile Computing (pp. 4342-4346).

Nurhajati, N., Rachma, N., Deka, R. E., \& Azwar, E. (2018). Inovasi disruptif: Tantangan dan peluang bagi UKM. INOBIS: Jurnal Inovasi Bisnis dan Manajemen Indonesia, 1(2), 214-226. doi:10.31842/jurnalinobis.v1i2.31.

OECD. (2018). SME and entrepreneurship policy in Indonesia 2018 (OECD studi). Paris: OECD. doi:10.1787/9789264306264-en.

Pereshybkina, A., Castillo Conde, M. E., \& Kalyesubula, T. (2017). Industry 4.0 scenario planning: How will the industry 4.0 transformations affect SMEs in Germany by 2030? Hochschule Furtwangen University.

Raymond, L., Uwizeyemungu, S., Fabi, B., \& St-Pierre, J. (2018). IT capabilities for product innovation in SMEs: a configurational approach. Information Technology and Management, 19(1), 75-87. doi:10.1007/s10799-017-0276-x.

Singh, R. K. (2011). Developing the framework for coordination in supply chain of SMEs. Business Process Management Journal, 174), 619-638. doi:10.1108/14637151111149456.

Omar, S. S., Arokiasamy, L., \& Ismail, M. (2009). The background and challenges faced by the small medium enterprises. A human resource development perspective. International Journal of Business and Management, 4(10), 95-102. doi:10.5539/ijbm.v4n10p95.

Smallbone, D., \& Welter, F. (2001). The role of government in SME development in transition economies. International Small Business Journal, 19(4), 63-77. doi:10.1177/0266242601194004.

Sulaksono. (2018). Kebijakan industri nasional di era disrupsi teknologi. In IPB Talk on Agroindustry 4.0: Tantangan dan Peluang bagi Sumberdaya Agroindustri. Bogor. 